телна активност в мозъка [24]. При пациенти с активен РА може да бъде променена мозъчната метаболитна активност на ниво centrum semiovale. В сравнение с пациенти с неактивен PA се отчита по-високо съотношение холин/креатин и доста по-ниско съотношение $\mathrm{N}$-ацетиласпартат/холин [25].

Невроизобразяването на мозъчните промени с МРТ е неинвазивно и високоинформативно. В подкрепа на правилната диагноза е необходима корелация с клинико-лабораторни данни - серология за ревматоидни фрактори, анализ на ликвор.

В литературата има по-малко данни за ревматоидни менингити, мозъчни васкулити и за вероятния механизъм на тяхното възникване. Категорична обаче е връзката на РА с атеросклерозата и риска от развитие на исхемични мозъчни инсулти. В този контекст остават и редица отворени въпроси: Дали хроничното възпаление при РА, което води до ендотелна диссункция, участва в патогенезата на болестта на малките мозъчни съдове; Има ли връзка между нивото на възпаление, продължителността и активността на възпалителния процес и засягането на мал- ките съдове; Дали своевременното откриване на мозъчни промени може да бъде прогностичен образен маркер за мозъчносъдова болест; Ранното откриване на безсимптомни мозъчни лезии изисква ли допълнителни механизми за съдова протекция и превенция на мозъка от исхемични инсулти?

Необходими са и допълнителни проследявания за свързаните с мозъчно засягане ефекти на различните медикаменти, използвани за лечение на РА.

Ревматоидният артрит създава хроничен проинфламаторен фон, на чийто терен възникват и мозъчни промени. МРТ заема водеща роля в идентифицирането на различните процеси на микро- и макроваскуларна исхемия, мозъчно възпаление и демиелинизация, атлантоаксиална сублуксация. Ранното оценяване и разбиране на тези промени, както и проследването за прогресия са от съществено значение за правилното управление на заболяването, компетентния избор на терапевтична стратегия и модифициране на имунната система, повишаването качеството на живот и индивидуалния подход при пациентите с ревматоиден артрит.

\title{
MRI BRAIN FINDINGS IN RHEUMATOID ARTHRITIS: A REVIEW OF THE LITERATURE
}

\author{
T. Zdravkova1,2, S. Tsvetkova1, D. Zlatareva ${ }^{2,3}$ \\ ${ }^{1}$ Department of Diagnostic Imaging, Medical University - Plovdiv \\ ${ }^{2}$ Translational neuroscience complex, Medical University - Plovdiv \\ ${ }^{3}$ Department of Diagnostic Imaging, Medical University - Sofia
}

\begin{abstract}
Rheumatoid arthritis (RA) is a chronic autoimmune inflammatory disorder that mainly attacks the joints and leads to early disability. Despite aggressive anti-inflammatory therapy, the risk of systemic complications remains high. Moreover, the rate of premature cardiovascular disease mortality in patients with active RA, as well as the risk for development of non-fatal cardiovascular and cerebrovascular complications is also high. Central nervous system (CNS) involvement is one of the main components of extra-articular manifestations of RA. Brain changes might be caused by systemic inflammatory response or by the drugs used for treatment. Assessment of brain involvement and its relationship to the characteristics of the disease in patients with RA are particularly useful. Early detection of changes without cerebral symptoms and rapid response in acute events are of particular importance. With the increasing use of more imaging modalities magnetic resonance imaging (MRI) has become highly specific, safe and non-invasive diagnostic tool for early detection and monitoring of different pathological processes involving the brain in patients with RA. Understanding MRI imaging findings in brain involvement is important for selecting appropriate treatment and control of disease progression. The aim of this review is to summarize literature data of brain changes in RA and their relationship with systemic inflammation as well as to demonstrate the role of MRI in their assessment.
\end{abstract}

Key words: Rheumatoid arthritis, brain changes, MR 


\section{INTRODUCTION}

The global prevalence of RA is approximately $1 \%$, increasing with age. RA is more common in women. There is geographic variation in RA incidence - it is higher in North America and North Europe.

The etiology of RA is probably multifactorial and interaction between different genetic, immunologic, and environmental factors may trigger the disease [1].

The most typical manifestation of RA is symmetrical involvement of peripheral joints. However, in large percentage of cases the aggressive inflammatory process may attack atlanto-axial articulation and lead to atlanto-axial instability and subluxation [2]. Despite the use of different successful therapies in patients with RA, the risk of systemic complications poses a significant challenge to overcome. It is therefore of utmost importance to develop a unified interdisciplinary imaging approach in RA diagnostics. Extra-articular manifestations of RA are different, they may involve more than one organ or system, especially the skin, cardiovascular and pulmonary systems. CNS does not remain isolated from systemic inflammation [3]. Up to date, no definitive data are available worldwide on the percentage of CNS involvement in patients with RA. Both systemic inflammatory process and medication used in RA treatment may cause structural brain changes. Metabolic brain changes have been reported during systemic inflammation.

In this review, we summarize literature, describing brain changes in patients with RA, as well as MRI characteristics of these changes.

\section{STRUCTURAL BRAIN CHANGES FROM THE SYSTEMIC INFLAMMATORY PROCESS}

The way how RA affects the brain has not been fully studied. Some authors suggest that CNS involvement occurs due the fact that chronic inflammation might alter blood-brain barrier (BBB) and the intracerebral activity of TNFa (tumor necrosis factor- $\alpha$ ). Experimental models in mice have demonstrated increased cerebrovascular permeability by inducing systemic inflammation with lipopolysaccharide and arthritis with collagen. Based on systemic inflammation, increased activity of TNFa in the brain is reported, which leads to activation of microglial cells. It is possible that the S100A4 protein mediates the process of increased permeability of the BBB to inflammatory cells in collagen-induced arthritis [4].

Systemic inflammation in RA can have direct or indirect effects on the CNS.
The direct effect of RA related inflammation presents with vasculitis, meningitis and choroid plexus infiltration, while the indirect effects are associated with cerebrovascular events.

Early but non-specific sign for CNS involvement from inflammatory process in RA is infiltration of the choroid plexus. It not only plays a key role in the homeostasis of the cerebrospinal fluid, but also performs a protective function to the brain parenchyma. That is why the enlargement of the plexus is considered a sign of a damaged BBB [5].

Cerebral vasculitis in RA, described in literature is rare. Rapid assessment and prompt diagnosis are vital for adequate therapy and favorable outcome. Cerebrovascular involvement is most common in patients with long lasting seropositive active RA. Both parenchymal and meningeal vessels are involved independently or as a part of systemic or isolated vasculitis [5]. The pathogenesis of vasculitis, as well as the trigger for inflammatory response remain unclear for now. Different studies suggest the theory for rheumatoid factor involvement and antibody-induced tissue injury in systemic vasculitis. A meta-analysis of 14 studies with more than 1500 RA patients revealed a significant association between rheumatoid vasculitis and three HLA-DRB1 shared epitope genotypes [6].

Clinically, cerebral vasculitis, present most commonly with chronic progressive headache, focal neurological signs such as paresis/hemiparesis, aphasia, diplopia, dysarthria, ataxia and seizures [7].

Rheumatoid meningitis is another rare complication of RA with pathogenesis not fully understood. It can be late manifestation, but it is also possible to be the first symptom of the disorder [8]. Rheumatoid meningitis can present with headache, quantitative disorders of consciousness, behavioral changes, paresis, cranial nerve dysfunction, meningeal irritation symptoms, and seizures [9].

RA patients are at increased risk of developing and progression of atherosclerosis compared with general population $[10,11]$. The atherogenic effect of chronic inflammation process involve few key steps: endothelial dysfunction, secondary dyslipidemia and coagulation activation. There are specific steps mentioned in RA, which accelerate the atherosclerotic process. T-lymphocyte subtype CD4+ CD28- increase have been reported (inflammatory cells with high potential for tissue injury). Their count is proven to be higher in unstable atherosclerotic plaques. However, the count of circulation endothelial progenitor cells (precursors of mature endothelium), involved in regeneration of endothelium after 
vascular damage is decreased. In conclusion, patients with RA have increased risk for vascular damage and impaired endothelium regenerative capacity [11]. Many studies have found association between $\mathrm{RA}$ and atherosclerotic plaques prevalence in carotid arteries. Janet E. Pope et al. noted accelerated growth of atherosclerotic plaques in carotid arteries in patients with active RA. The rapid plaque progression corresponds with hsCRP (High sensitivity C-reactive protein) and ESR (erythrocyte sedimentation rate). ESR is a good prognostic factor for the severity of the atherosclerosis while CRP for mortality due to cardiovascular diseases. Inflammatory process in active RA contributes to plaque instability, increasing the risk for cardio-vascular accidents [12].

Rapid progression of atherosclerosis in RA patients is probably related with the increased stroke rate. Studies found increased risk of ischemic stroke in patients with RA, especially at age bellow 50 years. TNF $\alpha$ and IL-6 (interleukin-6) lead to increased CRP levels, which is considered an independent risk factor for stroke. TNFa can also activate processes of thrombogenesis in endothelial cells [13, 14]. Alicia M. Zha et al, noted that the good control of the inflammation is important for cerebrovascular risk reduction. Analyzing different treatment strategies, they noted positive effects of methotrexate on improving lipid and metabolic profiles as well as for reducing the risk of stroke. A 3.9-year observational study has demonstrated reduced risk for cerebrovascular events with $35 \%$ in methotrexate treatment group compared to control group. A meta-analysis of 34 studies showed that treatment with TNF- $\alpha$ inhibitors reduce the risk of stroke with $43 \%$. The anti-inflammatory effect of corticosteroids does not overcome the risks with their prolonged use. Long-term treatment with corticosteroids modulates conventional risk factors like dyslipidemia, high blood pressure, insulin resistance and increased weight; therefore, increasing the risk of stroke or heart attack. Non-steroidal anti-inflammatory drugs (NSAIDs) intake is also associated with an increased risk of vascular events [15].

The control of the cerebrovascular risk relies not only on the assessment of carotid arteries and major intracranial vessels but also on small vessel changes identification.

The role of RA in small cerebral vessel (arterioles, capillaries, venules) involvement is not fully understood. Stewart J. Wiseman et al. support the theory, that systemic inflammation is related to small vessel disease and the fact that in most of rheumatic diseases there is an increase in asymptomatic cere- brovascular damages, presenting as white matter hyperintensities [14]. Further, EJ van Dijk et al. in a study with 1033 patients pointed out the inflammatory process as a reason for small vessels disease occurrence. Higher levels of CRP are correlated with progressive lesions in white matter (leukoaraiosis) and are not dependent on other cardiovascular risk factors [16]. Pogessi et al. also note the association between higher levels of the most used marker of inflammation - CRP and the progression of periventricular white matter hyperintensities and silent strokes [17]. Leukoaraiosis itself is a risk factor for cognitive impairment, stroke and an independent risk factor for cerebral reinfarction [18]. Cerebral microhemorrhages and lacunar infarction are considered an additional stroke risk factor. Some authors suggest that impaired vessel wall is prone to rupture and microhemorrage formation. Structural changes or impaired function of the vessel with consecutive chronic hypoperfusion are pointed out as a probable cause for ischemic lacunar lesions [17].

CNS changes could result not only as a direct inflammatory effect on brain, but also can be indirectly caused by involvement of the cervical segment of the vertebral column. The most prominent effect of the inflammatory process can be seen in small joints, but the second most affected location are the atlanto-axial synovial articulations. According to the epidemiological data in literature, the prevalence of cervical spine involvement in RA is $43 \%-86 \%$ [19]. Consequences of vertebral join involvement are ligament degeneration, atlanto-axial instability and atlanto-axial subluxation (AAS). ASS can be anterior, posterior or lateral. In case of odontoid apex migration towards foramen magnum, the condition is defined as vertical AAS, or basilar invagination $[2,20]$. Atlanto-axial instability and AAS can be asymptomatic and impairment of cervical spine may be found incidentally. Patients may present with neurological symptoms, which can be falsely interpreted as peripheral [19].

Inflammatory process may lead to retrodental pannus formation, which can damage posterior transversal ligament and when combined with AAS can lead to spinal cord and brainstem compression. The last can manifest with severe neurological symptoms or even death $[2,21]$. Any of the mentioned AAS types can contribute to altered vertebral artery position on its course towards first and second cervical vertebrae. This could potentially increase the risk for thrombosis, lead to vertebral artery occlusion and posterior circulation infarction [5, 21]. In advanced stages, tonsillar herniation or syringomyelia may appear $[22,23]$. We 
did not find definitive data in literature, regarding the incidence of the described types of complications in RA patients with proven atlanto-axial instability or AAS.

Early diagnostics of cervical vertebrae involvement in the setting of neurological symptoms presentation is of the greatest importance due to the potential risk of symptom progression, disability and lethality. In proven case of cervical vertebrae involvement, presented with neurological symptoms, treatment can be challenging and surgical stabilization might be considered. Fixation of cervical vertebrae aims to delay and prevent future neurological complications [19].

\section{BRAIN METABOLIC CHANGES RELATED WITH SYSTEMIC INFLAMMATORY PROCESS IN RA}

We have found few studies in the literature with inconclusive information about the association between systematic inflammation in RA and metabolic cerebral changes.

Levels of different brain metabolites, related with inflammatory activity in brain have been measured with magnetic resonance spectroscopy (MRS) in patients with RA. Such are myo-inositol (MI), brain choline (CHO), lactate (LAC) and $\mathrm{N}$-acetylaspartate (NAA) [24, 25]. Emmer at al. (2009) conclude that patients with RA have altered brain metabolic activity at centrum semiovale. Authors have used single voxel spectroscopy (SVS) and include 35 patients with RA. Compared with patients with non-active RA, patients with active RA have higher choline/creatinine ratio and lower $\mathrm{N}$-acetylaspartate/choline ratio.

These changes are related with the disease activity and correlate with ESR level [25]. Recently (January 2020), another research team have published results of its study with 18 RA patients. However, Christina Muller et al. used whole brain MRS and did not find metabolic constellation of inflammation in any of brain regions. In this study, an interesting positive correlation between ESR and $\mathrm{CHO}$ levels have also been found [24].

\section{BRAIN CHANGES FROM DRUG THERAPY}

Treatment with rituximab and immunosuppression in patients with RA, poses a potential risk for progressive multifocal leukoencephalopathy (PML) development [26]. PML is caused by reactivation of JC (John Cunningham) polyomavirus, which leads to oligodendrocyte destruction and appearance of multiple areas of demyelination in CNS [27]. It is supposed that the primary infection with JC virus occurs in childhood. This virus remains latent in "renal epithelial cells, lymphoid tissue, bone marrow and potentially in brain" [26]. In immunocompromised patients and immunosuppressive therapy, virus reactivation can lead to PML [28]. Clinically, PML can manifest with wide variety of symptoms and is associated with subacute neurological deficiencies visual and motor impairment, altered mental status and memory impairment $[26,27]$. In patients treated with rituximab, assessment for newly developed progressive focal neurological deficiencies is vital for excluding the diagnosis PML [26]. PML is a rare complication, usually lethal so immunosuppressive treatment should outweigh the risks.

\section{MRI MODALITIES AND IMAGING FINDINGS}

The usage of different sequences and the high tissue resolution of MRI are making it a preferred method for brain involvement assessment in RA. The standardized MRI protocol includes T1-weighted and T2-weighted images (T1W; T2W), FLAIR (fluid-attenuated inversion recovery), DWI (Diffusion Weighted imaging), SWI (Susceptibility Weighted imaging). TOF (Time of flight) angiography have been used for cerebral vessel assessment; MP angiography for demyelinating processes - T1W images with contrast. T1W images have been used for subcortical structures assessment and cortical thickness measurement. SWI is particularly useful for distinguishing hemorrhagic zones.

In patients with active large-vessel vasculitis, direct imaging signs of vasculitis can be seen - thickening of the vessel wall and intramural contrast enhancement. Indirect imaging signs of vasculitis are the findings of intraparenchymal or subarachnoid hemorrhage, microhemorrhages, ischemic lesions and vascular stenosis (Fig. 1) [29, 30].

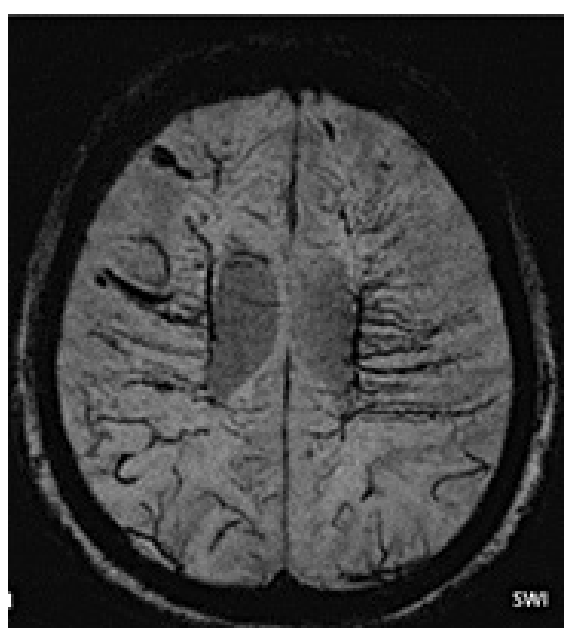

Fig. 1. Axial scan SWI-single microhaemorrhages. Irregularities on the walls of the vessels 
Multiple infarctions, usually bilateral, in different stage of evolution and randomly involving different vascular territories are suggestive of cerebral vasculitis.

Non-contrast enhanced MR angiography (3DTOF) can be particularly useful in the diagnosis of intracranial artery stenosis [29]. Contrast enhanced MR angiography may show changes in the arterial lumen in vasculitis - alternating regions of lumen narrowing and vessel dilatation - string-ofbeads sign $[5,30]$. Contrast-enhanced T1W images may show thickening of meninges and leptomeningeal enhancement in rheumatoid meningitis [9, 31].

Nonhomogeneous leptomeningeal contrast enhancement can be a sign of acute cortical ischemia or small-vessel vasculitis affecting meningeal vessels [5]. T2W is applied for identification of ischemic or glial processes. FLAIR is particularly useful sequence for detecting ischemic lesions in white matter near to brain-cerebrospinal fluid border and for evaluation of demyelinating processes [30]. DWI shows diffusion restriction minutes after the onset of ischemic stroke, differentiating between acute and chronic ischemia (Fig. 2) [32].

In the context of clinical presentation, MRI can support the diagnosis of PML. Understanding MRI characteristics of PML and differentiation of changes is essential for the early treatment of the disease.
In patients treated with rituximab PML presents with multifocal, bilateral symmetrical white matter lesions with sub- or/and supratentorial location. It can also present like a solitary unilateral lesion [33]. In case of supratentorial location, the lesions of white matter, primarily affect U-shape subcortical fibers and to lesser extent paraventricular and deep white matter. Lesions are presented with low T1W signal and high T2W/FLAIR signal [5]. Involvement of subcortical $U$-fibers is an important part of the lesions also in patients with multiple sclerosis and differentiation between white matter lesions in PML and multiple sclerosis can be challenging [34]. On DWI, zones with active demyelination are with increased signal, corresponding with process of limiting diffusion [33]. $D W I$ with apparent diffusion coefficients (ADC) is useful for detection of active infection and the stage of the disease. New active lesions and increasing rim of large lesions have diffusion restriction with increased signal of DWI and normal to low signal on ADC. That is, areas of active infection with cell edema correspond to a high signal for DWI and low $A D C$, which differentiates them from areas of reparative gliosis. Old lesions and the central area of large lesions have facilitated diffusion and give a low DWI signal and a high ADC [35].

Contrast-enhanced T1-weighted sequence is helpful I for evaluating the stage of demyelination
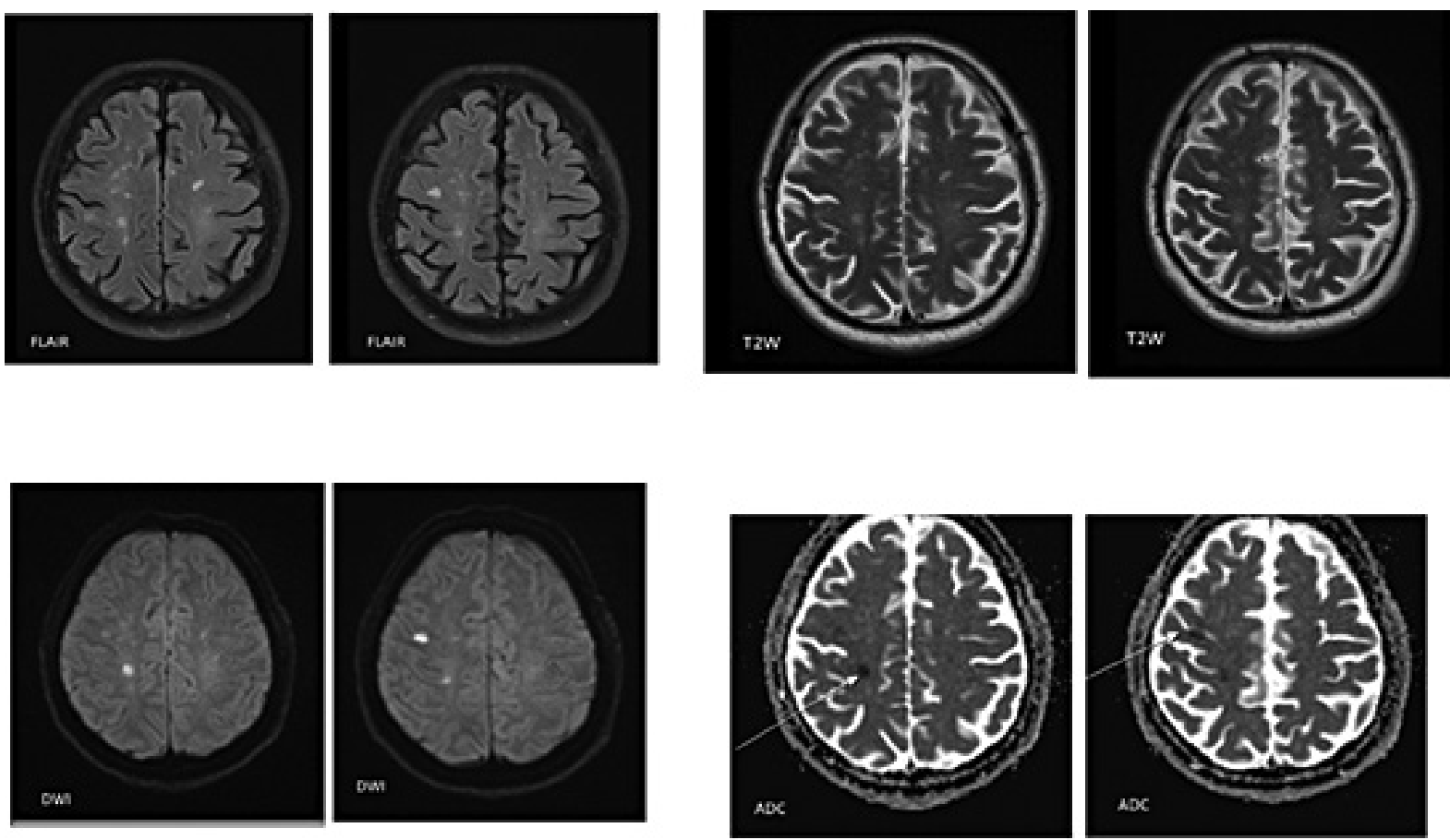

Fig. 2. Axial FLAIR, T2W, DWI and ADC slices demonstrate two foci of acute ischemia. An arrow indicates a reduced $A D C$ signal corresponding to a DWI hyperintense diffusion restriction 
and signs of inflammation. Lesions in patients taking rituximab can present with peripheral contrast enhancement. T2*-weighted images and SWI can show linear signal intensity on cortical-subcortical association with nearby demyelination areas of PML. In infratentorial location, lesions usually involve the cerebellum and have the same signal characteristics in the separated MRI sequences as the supratentorial lesions [33].

The probable involvement of the small cerebral vessels in the chronic inflammatory process inquires understanding of MRI characteristics of small-vessels diseases. According to the Standards for Reporting Vascular Shanges on Neuroimaging 2013 (STRIVE), MRI imaging in small-vessels disease include: small subcortical infarcts, lacunes, white matter hyperintensities, dilated perivascular spaces, microhemorrhages, and brain atrophy [36].

For infarction evaluation, T1, T2/FLAIR, DWI have been used. Lesions with size $>3 \mathrm{~mm}$ but less than $15 \mathrm{~mm}$ are associated with lacunar infarctions. In acute phase, they present with hypointense image in T1, hyperintense in T2/FLAIR and limited diffusion in DWI. Chronic lesions have similar to liquor signal characteristics in all sequences and hyperintense rim of marginal gliosis in FLAIR. Similar lesions > $15 \mathrm{~mm}$ are defined as subcortical infarctions [36, 37, 38].

3D T2* GRE or SWI sequences are used for detection of cerebral microhemorrhages. They present as small foci (T2* lesions) with very low signal intensity, which are not found in conventional MRI sequences [36, 37]. Periventricular white matter changes are hypointense or isointense in T1 and hyperintense in T2/FLAIR.

White matter hyperintensity as well as lacunae are also related with dilated periventricular spaces [36]. Evaluation of small cerebral vessels is a challenge in neuroradiology, with more dedicated MRI sequences introduced. One of the newest methods of evaluation of cerebral microcirculation with non-contrast brain perfusion is Arterial Spin Labeling (ASL) [39].

MRI has an irreplaceable role in evaluation of cervical vertebrae and detection of spinal cord compression in patients with RA. MRI has high sensitivity and specificity in evaluation of AAS; it provides important information for odontoid process position to foramen magnum. The method differentiates joint inflammatory changes, assesses for pannus formation and soft tissue involvement [2]. MRI is essential for evaluation of retro odontoid pannus, which leads to spinal cord compression. The different types of pannus - hypervascular pannus, hypovascular pan- nus, or fibrous pannus have different signal intensity in different sequences. Hypervascular pannus presents with hyperintense image in T2W [2]. If a persisting inflammatory process is suspected, T1FS sequence with contrast enhancement is used to show the increased pannus vascularization on post-contrast images [2, 20]. Image heterointensity indicates persisting edema and fibrosis into the pannus [20]. MRI provides exact evaluation of cervical spine and detects AAS. Bilateral infarctions in the area of vertebrobasilar artery with unknown onset is an indication for AAS evaluation [5].

\section{Proton Magnetic Resonance SPECTROSCOPY (H-MRS)}

MR spectroscopy is a non-invasive method for evaluating brain metabolic activity. Spectroscopy provides information as a spectrum - signals from different metabolites are plotted as peaks along a frequency scale. Depending on the choice, spectra can be obtained from one region in single voxel spectroscopy or from several regions in multivoxel spectroscopy [40]. Some of these metabolites, such as choline, myo-inositol, and lactate, are markers of inflammatory activity in the brain [24]. In patients with active RA, brain metabolic activity may be altered at the level of centrum semiovale. Compared to patients with inactive RA, patients with active RA have higher choline/creatinine ratio and lower $\mathrm{N}$-acetylaspartate/choline ratio [25].

Neuroimaging of brain changes with MRI is non-invasive and highly informative. Diagnostic process requires correlation of clinical features and laboratory findings - serology for rheumatoid factor, cerebrospinal fluid analysis.

\section{Discussion}

There is less data in the literature on rheumatoid meningitis, cerebral vasculitis and the probable mechanism of their occurrence. However, the relationship between RA and atherosclerosis and the risk of developing ischemic strokes is clear. In this context, a number of open questions remain: Whether chronic inflammation in RA, which leads to endothelial dysfunction, is involved in the pathogenesis of small vessels disease; Is there a relationship between the level of inflammation, the duration and activity of the inflammatory process and the involvement of small vessels; Whether the early detection of brain changes can be a prognostic image marker for cerebrovascular disease; Does the early detection of asymptomatic brain lesions require additional 
mechanisms for vascular protection and prevention of the brain from ischemic strokes?

Additional follow-up is also needed for the brain-related effects of the various drugs used to treat RA.

Rheumatoid arthritis creates a chronic pro-inflammatory background, based on which brain changes occur. MRI plays a leading role in identifying the various processes of micro- and macrovascular ischemia, brain inflammation and demyelination, atlantoaxial subluxation. Early assessment and understanding of these changes, as well as monitoring of progression, are essential for proper disease management, correct choice of therapeutic strategy and modification of the immune system, improving quality of life and personalized approach in patients with rheumatoid arthritis.

\section{Библиотека / References}

1. Silman AJ, Pearson JE. Epidemiology and genetics of rheumatoid arthritis. Arthritis research. BioMed Central, 2002, 4(3), 265272.

2. Mańczak M, Gasik R. Cervical spine instability in the course of rheumatoid arthritis-imaging methods. Reumatologia, 2017, 55(4), 01207.

3. Das S, Padhan P. An overview of the extraarticular involvement in rheumatoid arthritis and its management. Journal of Pharmacology and Pharmacotherapeutics, 2017, 8 (3), 8186.

4. Fuggle NR, Howe FA, Allen R, Sofat N. New insights into the impact of neuro-inflammation in rheumatoid arthritis, 2014,8 (OCT).

5. Ramaglia A, Gaudino S, Di Lella GM et al. The brain over the joints: MRI brain findings in Rheumatoid Arthritis, 2018, Available from: https://epos.myesr.org/poster/esr/ ecr2018/C-2684.

6. Bartels CM, Bridges AJ. Rheumatoid vasculitis: Vanishing menace or target for new treatments? Current Rheumatology Reports, 2010, 12(6), 414-419.

7. Akrout R, Bendjemaa S, Fourati H et al. Cerebral rheumatoid vasculitis: A case report. J Med Case Rep, 2012, 6, 302.

8. Schuster $\mathrm{S}$, Braass $\mathrm{H}$, lking-Konert $\mathrm{C}$ et al. Rheumatoid meningitis: A rare cause of aseptic meningitis with frequently stroke-like episodes. Neurology: Clinical Practice, 2018, 8(5), 451-455

9. Bourgeois P, Rivest J, Bocti C. Rheumatoid meningitis presenting with stroke-like episodes. Neurology, 2014, 82(17), 1564-1565.

10. Piepoli MF, Hoes AW, Agewall S et al. European Guidelines on cardiovascular disease prevention in clinical practice the Sixth Joint Task Force of the European Society of Cardiology and Other Societies on Cardiovascular Disease Prevention in Clinical Practice (constituted by representativ. Eur J Prev Cardiol, 2016, 23(11), NP1-96.

11. Van Leuven SI, Franssen R, Kastelein JJ et al. Systemic inflammation as a risk factor for atherothrombosis. Rheumatology, 2008, 47(1), 3-7.
12. Pope JE, Nevskaya T, Barra L, Parraga G. Carotid Artery Atherosclerosis in Patients with Active Rheumatoid Arthritis: Predictors of Plaque Occurrence and Progression Over 24 Weeks. The Open Rheumatol J, 2016, 10(1), 49-59.

13. Nadareishvili Z, Michaud K, Hallenbeck JM, Wolfe F. Cardiovascular, rheumatologic, and pharmacologic predictors of stroke in patients with rheumatoid arthritis: Anested, case-control study. Arthritis Care Res, 2008, 59(8), 1090- 1096.

14. Wiseman SJ, Ralston SH, Wardlaw JM. Cerebrovascular disease in rheumatic diseases a systematic review and meta-analysis. Stroke, 2016, 47(4), 943-950.

15. Zha AM, Di Napoli M, Behrouz R. Prevention of Stroke in Rheumatoid Arthritis. Current Neurology and Neuroscience Reports, 2015, 15(12), 1-10.

16. Van Dijk EJ, Prins ND, Vermeer SE et al. C-reactive protein and cerebral small-vessel disease: The Rotterdam scan study. Circulation, 2005, 112(6), 900-905

17. Poggesi A, Pasi M, Pescini F et al. Circulating biologic markers of endothelial dysfunction in cerebral small vessel disease: A review. Journal of Cerebral Blood Flow and Metabolism, 2016, 36(1), 72-94.

18. Marek M, Horyniecki M, Frączek M, Kluczewska E. Leukoaraiosis - New concepts and modern imaging. Polish Journal of Radiology, 2019, e76-e81.

19. Gillick JL, Wainwright J, Das K. Rheumatoid arthritis and the cervical spine: A review on the role of surgery. International Journal of Rheumatology, 2015, Article ID 252456, https:// doi.org/10.1155/2015/252456.

20. Jurik AG. Imaging the spine in arthritis - a pictorial review. Insights into Imaging, 2011, 2(2), 177-191.

21. Janssen I, Shiban E, Meyer B. Cervical spine involvement in rheumatoid arthritis: Diagnostics and treatment of instability due to rheumatism. Zeitschrift fur Rheumatologie, 2018, 77(10), 889-895.

22. Goel A. Is atlantoaxial instability the cause of Chiari malformation? Outcome analysis of 65 patients treated by atlantoaxial fixation. J Neurosurg Spine, 2015, 22(2), 116-127.

23. Wagner A, Grassner L, Kögl N et al. Chiari malformation type $\mathrm{I}$ and basilar invagination originating from atlantoaxial instability: a literature review and critical analysis. Acta Neurochirurgica, 2020, 162(7), 1553-1563.

24. Mueller C, Lin JC, Thannickal HH, et al. No evidence of abnormal metabolic or inflammatory activity in the brains of patients with rheumatoid arthritis: results from a preliminary study using whole-brain magnetic resonance spectroscopic imaging (MRSI). Clin Rheumatology, 2020, 39(6), 1765-1774.

25. Emmer BJ, van der Bijl AE, Huizinga TWJ, et al. Brain involvement in rheumatoid arthritis: $A$ magnetic resonance spectroscopy study. Arthritis \& Rheumatism, 2009, 60(11), 3190-3195.

26. Clifford DB, Ances B, Costello $C$ et al. Rituximab-associated progressive multifocal leukoencephalopathy in rheumatoid arthritis. Archives of Neurology, 2011, 68(9), 1156-1164.

27. Saribaş AS, Özdemir A, Lam C, Safak M. JC virus-induced progressive multifocal leukoencephalopathy. Future Virology, 2010, 5(3), 313-323.

28. Wiedinger K, Bitsaktsis C, Chang S. Reactivation of human polyomaviruses in immunocompromised states. Journal of NeuroVirology, 2014, 20(1), 1-8.

29. Küker W. Cerebral vasculitis: Imaging signs revisited. Neuroradiology, 2007, 49(6), 471-479.

30. Abdel Razek AAK, Alvarez H, Bagg $\mathrm{S}$ et al. Imaging spectrum of CNS vasculitis. Radiographics, 2014, 34(4), 873-894. 
31. Jones SE, Belsley NA, McLoud TC, Mullins ME. Radiologic-Pathologic Conference of the Massachusetts General Hospital. American Journal of Roentgenology, 2006, 186(4), 1181-1183.

32. Okorie C, Ogbole G, Owolabi M et al. Role of diffusion-weighted imaging in acute stroke management using low-field magnetic resonance imaging in resource-limited settings. West African Journal of Radiology, 2015, 22(2),61.

33. Alleg M, Solis M, Baloglu S et al. Progressive multifocal leukoencephalopathy: MRI findings in HIV-infected patients are closer to rituximab-than natalizumab-associated PML. European Radiology, 2020, 1. https://doi.org/10.1007/s00330-020-07362-y

34. Berger JR, Aksamit AJ, Clifford DB et al. PML diagnostic criteria: Consensus statement from the AAN neuroinfectious disease section. Neurology, 2013, 80(15), 1430-1438.

35. Bergui M, Bradac GB, Oguz KK, et al. Progressive multifoca leukoencephalopathy: Diffusion-weighted imaging and pathological correlations. Neuroradiology, 2004, 46(1), 22-25.

Постъпил за печат: 12.03.2020 2.

$\triangle$ Адрес за кореспонденция:

Тина Ярославова Здравкова

Катедра по образна диагностика

Медицински университет

бул „Васил Априлов“ 15-А

4002 Пловдив

тел.: 0887989288

e-mail: tinazdr@mail.bg
36. Wardlaw JM, Smith EE, Biessels GJ et al. Neuroimaging standards for research into small vessel disease and its contribution to ageing and neurodegeneration. The Lancet Neurology, 2013, 12(8), 822-838.

37. Ikram MA, van der Lugt A, Niessen WJ et al. The Rotterdam Scan Study: design update 2016 and main findings. European Journal of Epidemiology, 2015, 30(12), 1299-1315.

38. Staals J, Makin SDJ, Doubal FN et al. Stroke subtype, vascular risk factors, and total MRI brain small-vessel disease burden. Neurology, 2014, 83(14), 1228-1234.

39. Zhang Q, Stafford RB, Wang Z et al. Microvascular perfusion based on arterial spin labeled perfusion MRI as a measure of vascular risk in Alzheimer's disease. ournal of Alzheimer's Disease, 2012, 32(3), 677-687.

40. Öz G, Alger JR, Barker PB et al. Clinical proton MR spectroscopy in central nervous system disorders. Radiology, 2014, 270(3), 658-679.

Submitted: 12.03 .2020

$\triangle$ Correspondence address:

Tina Yaroslavova Zdravkova

Department of Diagnostic Imaging

Medical University

15-A "Vasil Aprilov" blvd.

4002 Plovdiv

tel.: 0887989288

e-mail: tinazdr@mail.bg 